\title{
Journey to Transylvania: The 1991 ALA Colloquium on Library Science
}

By Opritsa D. Popa

Business Librarian

University of California, Davis

\author{
and Robert P. Doyke
}

Director, ALA/USIA Library/Book Fellow

Program

American Library Association

\section{An ALA delegation introduces Romanian librarians to modern library services and operations.}

A t the height of the revolution in Romania that brought down the Ceausescu regime, the American Library Association (ALA) pledged "totake a leadership role in helping restore libraries and library services in Romania." One fulfillment of the promise made by ALA in January 1990 was the organization of a colloquium on current topics in U.S. librarianship for Romania's librarians. Hekd from August 10-12, 1991, in the picturesque medieval city of Brasov in Transylvania, the meeting featured presentations by 13 American librarians, all of them nationally known educators and managers, led by ALA President-Elect Marilyn Miller. The ALA colloquium, sponsored by the National Library of Romania, took place at a crucial historical time when progressive ideas could fundamentally affect the course of scholarship in the country and the development of library policies and services.

Secluded behind the Iron Curtain, Romania was isolated from all Western scholarly thought for $\mathbf{4 6}$ years. State control over publishing, censorship, surveillance of contacts with foreigners, and a general atmosphere of distrust were day-to-day realities for librarians. After the bloody uprising of late 1989, however, a revolution of sorts also took place at the National Library, which oversees all Romanian public libraries. Librarians moved to replace their communist director with a library professional they felt could respond to the changing needs of a societyin transition. In early 1991 Gheorghe Bercan became the country's first "democratically elected" National Library director.
With a collection of more than eight million volumes, the National Library is the second largest in Romania. Director Bercan inherited the high expectations of a new era in all the nation's libraries: the urgent need for updated information in every field of knowledge, calls for immediate modemization of library services and operations, and demands for library education and training. Confronted with this pressure for new services and better access, Romania's library community sought advice from Western colleagues. Through a generous grant from the International Research and Exchanges Board (IREX) and at the invitation of the National Library, ALA responded with the Colloquium on Library Science.

The ALA colloquium had several goals: topresent an overview of U.S. library and information science; to help strengthen the new university-level library science curriculum in Romania; and to promote the adoption of international library standards, thus facilitating access to scholarly resources. For the American delegates, the meeting was an opportunity to enrich their own professional experience as well as to increase intemational understanding and scholarly cooperation by establishing personal and professional relationships with Romanian librarians.

\section{The colloquium}

A visit to the National Library in Bucharest and a discussion with Romanian librarians was the first item of the itinerary of the U.S. delegation. In August 1991, one-and-a-half years after the fall of 
Ceausescu, the capital still bore deep scars of violence. Bullet holes were visible on many buildings, graffiti still called for people to join the revolution, and candles burned at makeshift street altars for those who died in the fight for freedom. The blackened hull of the Central University Library in Palace Square, a vivid reminder of the long and destructive battle for the city, was veiled in scaffolding. "The sight of the ruined Central University Library was absolutely heart-wrenching," Marilyn Miller remarked. "[It represented] the destroyed record of a nation, the irreplaceable loss of treasures, and the betrayed trust of scholars, writers, teachers, and students. No matter how many times we passed the site ... the emotional reaction never lessened."

At the National Library an enthusiastic welcome awaited the Americans in the form of warm speeches, traditional Turkish coffee, and tsuica (plum brandy). Librarians had also created an exhibit featuring representative titles received by the library through the ALA/USIA Books for Romania project. Over the last two years this highly successful book drive has resulted in donations of approximately a quarter of a million scholarly books and journals to Romanian libraries. The ALA group was delighted to see that the gifts had reached their destination, and a visit to the stacks revealed that much of the material had been cataloged promptly and was already in heavy demand.
Reporters from the library media and members of the local press were on hand in Brasov, where 150 librarians from all corners of the country had gathered for the ALA colloquium. They represented public, academic, and special libraries, as well as the new library school in Bucharest which opened in September 1990. For the next three days the U.S. librarians made formal presentations in English, with simultaneous translation, on a host of current library topics including management, education, censorship, interlibrary cooperation, and public and technical services. Vigorous debate and intensive discussions among the Romanian librarians characterized all the colloquium sessions, as well as the social and cultural events held afterwards.

Participants heard from ALA library leaders who represent many years of experience in their specialties. Marilyn Miller (University of North Carolina, Greensboro) discussed the missions and goals of library education as well as curricula and accreditation. She also offered the group an overview of both children's services in U.S. public libraries and school library media programs, and delighted audience members with children's books and posters sent by American publishers.

Romania's newly formed democratic library associations are struggling to establish a strong professional presence in the country. Robert P. Doyle, director of the ALA/USIA Library/Book Fellows

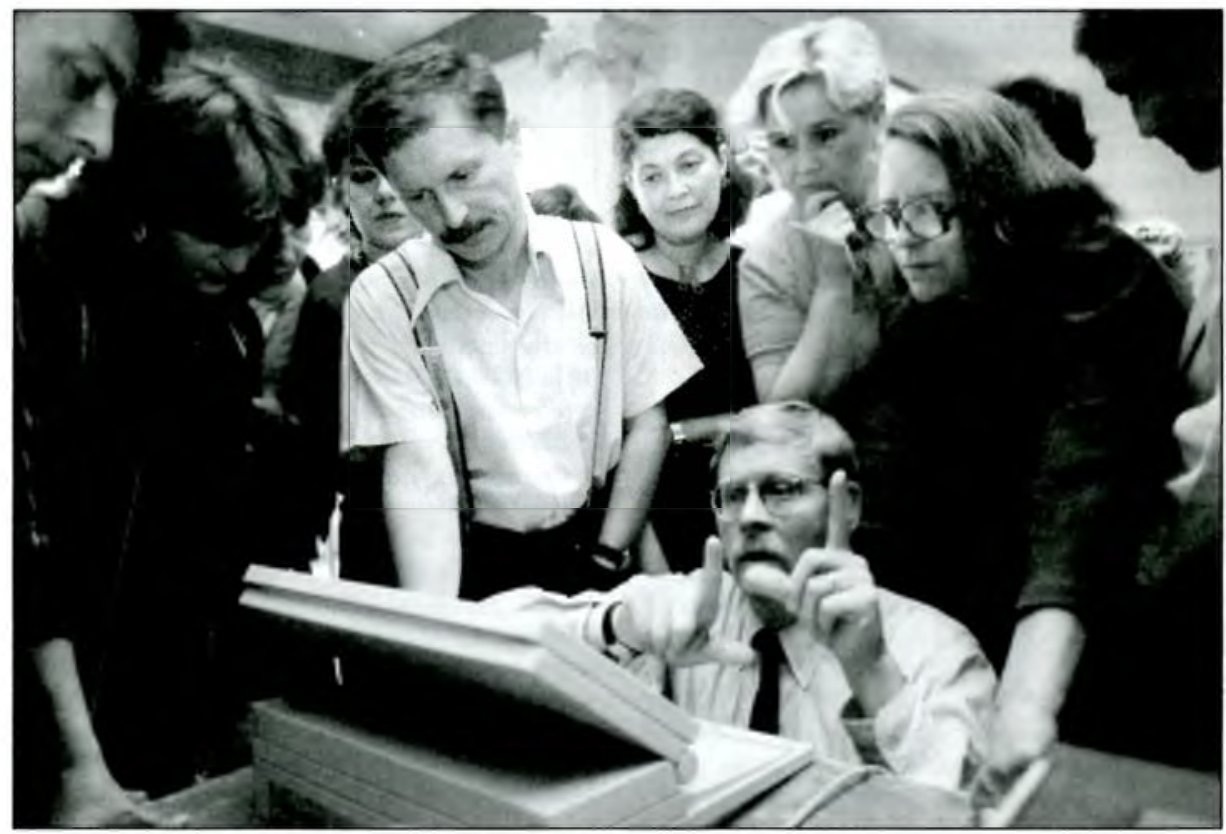

"I knelt before the machine and almost hid under the table as they crowded around the screen," said Edward Valauskas of the Superconductor Collider Lab in Dallas, who demonstrated modern computers to Romanian librarians. 
Program, spoke on the missions, activities, and budgets of library associations. Later in the colloquium Doyle talked about intellectual freedom and censorship at a hushed and intense session. The quiet atmosphere seemed to reflect the Romanian participants' reverence for concepts that until recently had been branded as heresy. "Listening to Bob's paper, I understood that intellectual

\section{"The sight of the ruined Central University Library was abso- lutely heart-wrenching. . . No matter how many times we passed the site ... the emotional reaction never lessened."}

freedom is a difficult course and one that is under constant fire in any society," said ALA representative James Moldovan (United States Court of Appeals, San Francisco). "The students who died in the December 1989 revolution were fighting for the very subject of his paper."

Jordan Scepanski (California State University, Long Beach) and Anita Breland (IBM) lectured on library organization and management, offering upto-date models that featured organizational charts, job descriptions, different management styles, and paradigms for decision-making and budgeting. The Romanian librarians seemed very receptive to Western management ideas.

Parallel discussions of public and technical services took up an entire day of the meeting, with more than 60 percent of the participants attending the technical services section. At that session, Nancy John (University of Illinois at Chicago) gave the audience an overview of technical services in U.S.

\section{Share your opinion with $C \& R L$ News readers}

Do you feel strongly about a particular issue and want to share your thoughts with a wider audience than just your colleagues down the hall? Now you have the opportunity to share your thoughts with a national audience. C $\& R L$ News is looking for wellreasoned commentaries on issues of interest to academic and research librarians for its new column,"The Way I See It." Essays should be between 500-750 words and should be sent to "The Way ISee It," C $\checkmark R L N e w s, A C R L, 50$ E. Huron St., Chicago, IL60611-2795; fax: 312-280-7663; e-mail: U38398@UICVM. libraries. "The discovery of the large number of librarians practicing cataloging with enthusiasm and skill was indeed a pleasant surprise," she observed.

Joseph Boissé (University of California, Santa Barbara) covered the history, philosophical base, and strategies for collection development for the group. "Our Romanian colleagues work under very difficult conditions," he commented, "yet their commitment to excellence in library service is no less solid than our own." Boissé and John together presented a program on fundamentals of resource sharing in libraries. Also on the technical services slate was Elaine Svenonius (University of California, Los Angeles); numerous articles in Romanian professional journals had indicated there was a strong interest among the country's librarians in her topic-thesaurus construction.

On the public services side, the Romanians were particularly interested in reference. A torrent of questions repeatedly interrupted a talk on reference services given in Romanian by Opritsa Popa (University of California, Davis). Information and referral services, business reference, literacy programs, and children's services as expressions of response to community needs were new concepts to the audience. For at least ten minutes, participants forgot about the speaker and argued loudly and intensely about the feasibility and benefits of various services. The American delegation could only look on, amazed at the passions unleashed by mere descriptions of library services. This extraordinary reaction made us realize that we were in fact "exporting" a democratic philosophy of library service dedicated to the benefit of the community. In the end, this may be one of the most important legacies of the ALA colloquium.

Lucinda Covert-Vail (San Francisco State University) gave the Romanian librarians a comprehensive overview of compact disc technology in libraries, a topic new to most of them. Participants were clearly fascinated by the volume of information included on CD-ROM discs and by the sophisticated search strategies and system features now available.

Computer demonstrations by Edward J. Valauskas (Superconductor Collider Laboratory, Dallas) were a main attraction of the three-day proceedings. "I have never had a reception like the one I experienced in Romania," Valauskas said. In the automated Grolier's Encyclopedia, participants searched for entries on Transylvania, Bucharest, vampires, and Moldavians; in Facts on File, they found articles on the country's recent political history, and they called up maps of Eastern Europe searching for Brasov and the surrounding area. The level of conversation rose as the Romanian librarians pressed closer and closer to the computer. "I knelt before the machine and almost hid under the table as theycrowded around the screen,"Valauskas 
reported. "All I could do was look on and smile. I have never had a class in which I was so happy to see the students take over."

Sharing the podium for a session on library automation were S. Michael Malinconico (University of Alabama) and Vinod Chachra (VTLS, Inc.). Malinconico gave a detailed and highly illustrated explanation of library and electronic technologies. including benefits, justifications, and products and services, with special emphasis on North American applications. Based upon examples drawn from the VTLS system, Chachra demonstrated integrated library systems. Malinconico, who had visited Romania in 1987 , commented on the desire of the audience for progress and the limitations of their situation: "The Romanian computer specialists were extremely frustrated. They know all too well the benefits that could be achieved with technology. They have the ability to do it-they only lack the means."

There was ample time outside colloquium sessions for the ALA delegation to socialize and learn more about their Romanian colleagues. The Romanians talked of their "losing battle" for bibliographic control due to the recent exponential growth of journal titles and the appearance and disappearance of publishing houses virtually overnight. They spoke movingly about the joy of rediscovering modern Western literature. U.S. librarians also visited the main historic and cultural sites of the region, among them the medieval Black Church in Brasov, several repositories of research materials, Count Dracula's castle in Bran, a 16th-century monastery in Curtea-de-Arges, and several colorful villages. The local and regional press recorded the delegation's journey in newspapers and on national television. All along the Americans' route, mayors, prefects, and ordinary people came out to greet them enthusiastically, offering bread and salt, tsuica, and music. "Viva Americanii! Long live the Americans!" was a favorite salutation. "The genuine affection the Romanian people have for Americans is humbling," said Joseph Boissé. "I could not have felt more welcome."

\section{Conclusions}

In retrospect, all members of the ALA delegation were impressed by the spirit of the Romanian people, which has survived miraculously unspoiled throughout the bleakyears of communism. "Romaniatouched me personally and professionally in very many ways," recalls Nancy John. "T'll always remember a few experiences in particular: the enthusiastic welcome of townspeople, holding Napoleon's personal copy of Catullus in my own hand, the destruction caused by a tyrant, the excitement of an emerging democracy ("No, we don'thave a constitutionyet!"), and the role Romanian librarians will play in it, and finally enjoying the warmth that comes from a shot of plum brandy any time of day when you are drinking it with good friends, new and old. As I sit in my office trying to manage the avalanche of paper, all of a sudden a few strains of music, a smell, a face pierce my consciousness. I laugh or smile, and know I'll never be the same person again."

ALA President-Elect Marilyn Miller concluded that the group had well fulfilled its task of delivering a series of lectures on librarianship, U.S.-style. "But

\section{The American delegation could only look on, amazed at the passions unleashed by mere descriptions of library services.}

what we gained may have been more important. We came away with profound respect for the Romanian librarians who have struggled to keep their libraries alive for 46 years. They have done this in the face of political oppression and manipulation, personal intimidation, the absence of financial support, and isolation from the developments in their profession." Miller pointed out the Romanian librarians' overwhelming need for collegiality, up-to-date preparation programs, the modernization of collections, financial support, and technology. "The temptation is very strong to urge ALA to adopt Romania in order to help demonstrate library development strategies that could be used by other countries that have also been intellectually, socially, politically, and emotionally isolated from the rest of the world."

Our educational journey to Transylvania ended. Did we accomplish our goals? The answer must be an emphatic "yes," but much more remains to be done. Jordan Scepanski emphasized that training of both rank-and-file librarians and library administrators for more than just a few days was needed. "The investment that will most profit Romaniaand the profession at large is one made immediately —in people."

\section{Put CURL News on your mailing list}

C\&RL News likes to include short, practical items of interest to our readers. Many of these iterns are picked up from brief notices read in library newsletters Many of the personnel changes, notices of acquisitions and grants, and new notes we report are also picked up from these newsletters.

If your library or institution has a newsletter please be sure C $d R L$ News is on your mailing list. Newsletters should be sent to: Editor, $C$ \& $R L$ News, 50 E. Huron St., Chicago, IL 60611. 